\title{
METHODS OF EVALUATION OF EFFICIENCY OF THE ENTERPRISE
}

\author{
Chazov Y. \\ Zaporizhia National University \\ Ukraine, 69600, street Zhukovsky, 66, Zaporizhia \\ zhenyavarenya@gmail.com
}

Key words:

efficiency, economic efficiency, efficiency indicators, approaches to evaluation of enterprise efficiency.
The article provides a definition of efficiency, from an economic point of view. The general classification of efficiency indicators used for business evaluation is reflected. They, in turn, are divided at the level of qualifications: The level of economic activity, cost ratio, method of calculation, completeness of the components of costs and results, the object of evaluation, the stage of calculation, the method of calculation. The characteristic concerning each qualification sign is given. The main approaches to assessing the effectiveness of the enterprise are reflected. They are divided into: the classical approach, the concept of sustainable economic growth and modern theory of financial management. The characteristics of each of the approaches are given. It is concluded that the combination of these approaches and the identification of criteria that reflect the efficiency of the enterprise, but are not reflected in the main approaches to assessing the effectiveness of the enterprise.

\section{МЕТОДИ ОЦІНКИ ЕФЕКТИВНОСТІ ПІДПРИЕМСТВА}

\author{
Чазов Ю.В. \\ Запорізький національний університет \\ Украӥна, 69600, вул. Жуковського, 66, м. Запоріжжяя \\ zhenyavarenya@gmail.com
}

\section{Ключові слова:}

ефективність, економічна ефективність, показники ефективності, підходи до оцінки ефективності підприємства.
У статті наведено визначення ефективності 3 економічної точки зору. Відображено загальну класифікацію показників ефективності, що використовуються для оцінки бізнесу. Вони, в свою чергу, поділяються за рівнем кваліфікації: Рівень економічної активності, коефіцієнт витрат, спосіб розрахунку, повнота складових витрат і результатів, об'єкт оцінки, стадія калькуляції, метод калькуляції. Дається характеристика щодо кожного кваліфікаційного знака. Відображено основні підходи до оцінки ефективності діяльності підприємства. Вони поділяються на: класичний підхід, концепцію сталого економічного зростання та сучасну теорію фінансового управління. Наведено характеристики кожного 3 підходів. Зроблено висновок, що поєднання цих підходів та визначення критеріїв, що відображають ефективність діяльності підприємства, але не відображаються в основних підходах до оцінки ефективності діяльності підприємства.

\section{Statement of the problem}

Economic efficiency is one of the main categories associated with achieving the strategic goal of enterprise development. The main problem in assessing and applying the means of improving the economic efficiency of enterprises is to obtain the best financial results, provided the most efficient use of all available resources. With the development of market relations determines the specifics of the operation of enterprises, as the level of risk increases, competitiveness increases, allows to adapt to economic changes. In order to survive in these conditions, increase their efficiency and competitiveness in a particular market and search for new ones. The efficiency of the enterprise should be based on achieving the optimal level of costs, while ensuring the appropriate quality of goods or services.

\section{Analysis of recent studies and publications}

This question was studied by such scientists as Rogulenko T.M., Pozov D.A., Sharkova A.V., Kilyachkov A.A., Markina E.V., Dashkov, B.A. Reisberg and others. The essence of "effectiveness" and "efficiency" is revealed in the works of these scientists. Others define the criteria and systems of production efficiency indicators.

\section{The main material of the research}

The attractiveness of entrepreneurial activity depends on the degree of satisfaction of its results by people who 
invest in a particular business. Each investor has his own goals and preferences, expects a certain end result, opening his own business. In general, the more a business meets the needs of an investor, the more efficient it is.

The very concept of "efficiency" is interpreted by different authors depending on its scope. From an economic point of view, efficiency is the ratio of result indicators (effect) and costs (or the sum of resources) used to achieve it (table 1) [1].

Consider another definition of "efficiency" - the relative effect, effectiveness of the process, operation, project, defined as the ratio of effect, result, to costs, the costs that caused it to ensure its receipt [1].

Thus, economic efficiency reflects the relationshipbetween performance and costs incurred for its implementation.

The general classification of indicators used to assess business performance is given below [2].
The system of global indicators covers the macro level, and local ones reflect the efficiency of specific enterprises.

It should be noted that different approaches are used to assess economic efficiency, which can be combined into cost and resource (fig. 1).

The cost approach comes down to the fact that when calculating the performance indicators, the result is correlated with the cost of resources aimed at obtaining this result.

The resource approach involves comparing the result not with the amount of resources expended, but with the cost of resources used in the process of obtaining the result.

The system of absolute indicators shows the natural and cost expression of the obtained result. Relative indicators characterize the quality or level of return on resources used and costs incurred.

Table 1 - Classification of enterprise efficiency indicators

\begin{tabular}{|c|c|}
\hline Classifications & Types of indicators \\
\hline \multirow{2}{*}{ Level of economic activity } & Global \\
\hline & Local \\
\hline \multirow{2}{*}{ Cost ratio } & Expensive \\
\hline & Resource \\
\hline \multirow{2}{*}{ Method of calculation } & Absolute \\
\hline & Relative \\
\hline \multirow{2}{*}{ Completeness of component costs and results } & Generalizing \\
\hline & Partial \\
\hline \multirow{5}{*}{ Object of evaluation } & Resource efficiency \\
\hline & Efficiency of capital expenditures \\
\hline & Efficiency of innovations \\
\hline & Efficiency of operation, agreement, project \\
\hline & $\begin{array}{l}\text { The efficiency of the enterprise as a whole, or its individual } \\
\text { components (production, commercial, financial, investment) }\end{array}$ \\
\hline \multirow{3}{*}{ Calculation stage } & Design \\
\hline & Planned \\
\hline & Actual \\
\hline \multirow{2}{*}{ Method of calculation } & Straight \\
\hline & Reverse \\
\hline
\end{tabular}

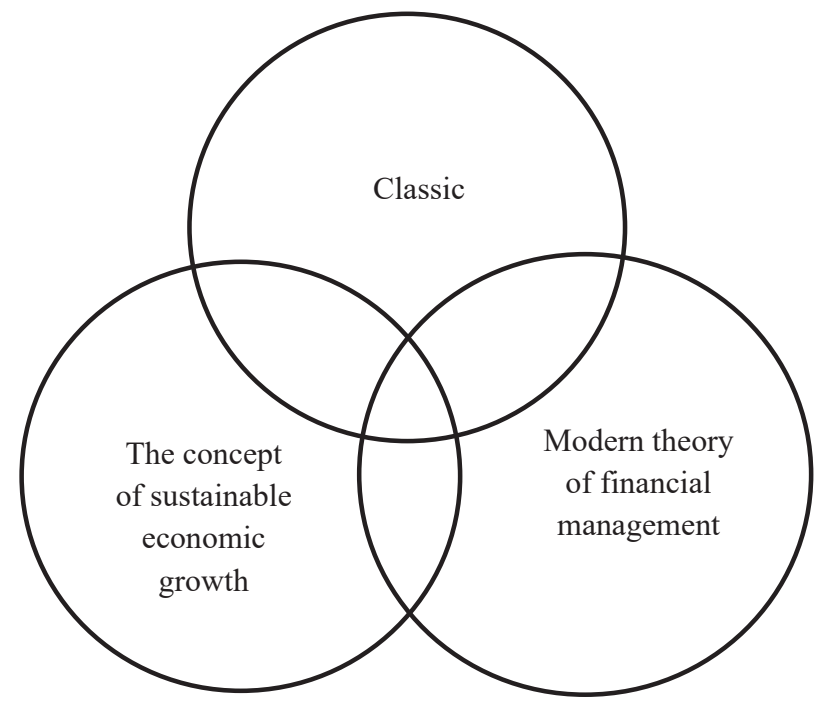

Fig. 1. Basic approaches to assessing the efficiency of the enterprise [3] 
Summary indicators characterize the efficiency of the business as a whole, and take into account the overall results and the amount of resources consumed.

Private indicators characterize the level of return of any specific resource, process, unit, etc.

In the process of financial management of the business should predict its effectiveness in the future, set planned current parameters and evaluate the actual results of activities.

Direct and inverse indicators are characterized by differences in calculation. Direct assumes the comparison of the result to the costs (level of return), and inverse the costs to the amount of the result (the level of resource consumption).

Each of the above groups includes specific indicators that are criteria for assessing business performance.

As key indicators that traditionally characterize the efficiency of the enterprise, we can distinguish the following - profitability, cost level, return on assets, turnover ratio, capital intensity, productivity, and others.

The development of economic science and practice contributes to the improvement of tools for evaluating and managing business efficiency.

\section{Conclusions}

The classical approach to efficiency assessment is based on the entrepreneur's focus on the end result in the form of profit. In essence, this is an accounting approach based on the analysis of financial statements. The key performance indicators here are profitability indicators. This approach is quite justified, although it has its drawbacks due to the fact that current profits are not always able to provide the desired pace of business development.

The concept of sustainable economic development of the enterprise provides a focus on maintaining its stability at all stages of the planned strategy. This approach places more emphasis on maintaining the company's position and minimizing possible risks, ie its economic security.

The modern concept of financial management tends to increase the return on capital from investing in a particular business, taking into account all possible sources of its profitability. That is, in addition to current profitability and indicators that characterize financial stability, the end result is taken into account, which reflects the actual efficiency of entrepreneurial activity - the value of the business. Under effective financial management, the company's value will show steady growth, providing a decent return on investment. This approach is costly.

In this regard, it is obvious that the modern approach to evaluating and managing the efficiency of the enterprise should include not only the traditional set of indicators characterizing the overall results and costs, level of return and consumption of resources, but also the dynamics of business value as a key criterion for evaluating its efficiency.

The combination of cost and accounting approaches allows not only to reflect the state of the business, which is assessed on the basis of internal reporting and information, but also its strategic perspectives, taking into account the presence of external factors and indicators. This comprehensive approach is able to give the most objective view, both business owners and other categories of users interested in this information.

\section{References}

1. Rogulenko Tetyana Mykhailivna, Lawsuit of Dionis Anastasovych. Evaluation of business efficiency. Visnyk of GUU. [Electronic resource], 2015. № 4. Access mode: https://cyberleninka.ru/article/n/otsenka-effektivnostibiznesa/ (access date: 17.04.2019).

2. Dictionary of financial and economic terms / Sharkova A.V., Kilyachkov A., Markina E. Moscow : Dashkov and K, 2017. $1168 \mathrm{p}$.

3. Modern economic dictionary / B.A. Reisberg, L.Sh. Lozovsky, E.B. Starodubtseva. 6th ed., Revised. and ext. Moscow : INFRA-M, 2019. 512 p. 